\title{
MPET4: a computer program for coexisting garnet- clinopyroxene-plagioclase-quartz geothermobarometry
}

\author{
H. Thomas \\ Department of Geology, Banaras Hindu University, Varanasi 221 005, India
}

\begin{abstract}
The paper deals with the computer program to calculate temperature (in ${ }^{\circ} \mathrm{C}$ ) and pressure (in kbar) based on assemblages garnet-clinopyroxene-plagioclase-quartz, and following reactions:

(a) $1 / 3$ Pyrope + Hedenbergite $=1 / 3$ Almandine + Diopside,

(b) Anorthite + Diopside $=2 / 3$ Grossularite $+1 / 3$ Pyrope + Quartz,

(c) Anorthite + Hedenbergite $=2 / 3$ Grossularite $+1 / 3$ Almandine + Quartz.

The program is written in Microsoft Quick Basic for IBM XT/AT compatible machines running MSDOS Version 3.0 or higher. The user can acquire a copy of program by sending the author a 3.5"/5.25" $\mathrm{DD} / \mathrm{HD}$ floppy diskette. The executable code of the computer program is MPET4.EXE.
\end{abstract}

\section{INTRODUCTION}

Several geothermometers and geobarometers have been formulated during the last 20 years for garnet-clinopyroxene-plagioclase-quartz assemblage. With the improvement of geothermobarometers, the activity composition relations poses a problem of formulation because of non-ideality for most of the minerals and garnet in particular. In order to make the calculations faster, the author has developed a program, "MPET4", for pressuretemperature calculations, using different formulations given by different workers.

The Fe-Mg exchange reactions between garnet (Gt) and clinopyroxene (Cpx) given by Mysen and Heier (1972), Raheim and Green (1974), Ellis and Green (1979), Ganguly (1979), Wells (1979), Dahl (1980), Ganguly and Saxena (1987) and Yang (1994) are used for geothermometric calculations. The Fe$\mathrm{Mg}$ exchange reaction of garnet-clinopyroxene is as follows:

$$
\begin{aligned}
1 / 3 \mathrm{Mg}_{3} \mathrm{Al}_{2} \mathrm{Si}_{3} \mathrm{O}_{12}+\mathrm{CaFeSi}_{2} \mathrm{O}_{6} & =1 / 3 \mathrm{Fe}_{3} \mathrm{Al}_{2} \mathrm{Si}_{3} \mathrm{O}_{12}+\mathrm{CaMgSi}_{2} \mathrm{O}_{6} \ldots . . . \text { (a) } \\
\text { Pyrope + Hedenbergite } & =\text { Almandine }+ \text { Diopside }
\end{aligned}
$$

To explain geobarometry properly, the author had considered the net transfer reaction of garnetclinopyroxene-plagioclase-quartz (GCPQ) equilibria. These mineral pairs are commonly found in the assemblages of metabasic and hence are suitable for estimating equilibrium pressure of most metamorphic rocks.

For this, the author has considered the Newton and Perkins (1982), Eckert et al. (1991), Holland and Powell (1985) calculated by Eckert et al. (1993), Holland and Powell (1990) calculated by Eckert et al. (1993), Berman (1988) calculated by Eckert et al. (1993) and Berman (1988) using Ca-Mg-Fe subregular solution of mixing in garnet of Berman (1990) calculated by Eckert et al. (1993) and Moecher et al. (1988). The equation of equilibrium is as follows:

Anorthite + Diopside $=2 / 3$ Grossularite $+1 / 3$ Pyrite + Quartz ...... (b) Anorthite + Hedenbergite $=2 / 3$ Grossularite $+1 / 3$ Almandine + Quartz ... (c)

\section{BACKGROUND OF GARNET-CLINO- PYROXENE GEOTHERMOMETERS}

Distribution of ferrous iron and magnesium between coexisting silicate minerals is the basis of important geothermometers for metamorphic rocks of wide interest. The exchange reaction is:

$1 / 3 \mathrm{Mg}_{3} \mathrm{Al}_{2} \mathrm{Si}_{3} \mathrm{Ol}_{2}+\mathrm{CaFeSi}_{2} \mathrm{O}_{6}=1 / 3 \mathrm{Fe}_{3} \mathrm{Al}_{2} \mathrm{Si}_{3} \mathrm{O}_{12}+\mathrm{CaMgSi}_{2} \mathrm{O}_{6} \ldots \ldots$. (a)

Pyrope + Hedenbergite $=$ Almandine + Diopside 


\section{H. Thomas}

The partition coefficient, $\mathrm{K}_{\mathrm{D}}=(\mathrm{Fe} / \mathrm{Mg})^{\mathrm{Gt}} /(\mathrm{Fe} /$ $\mathrm{Mg})^{\mathrm{cpx}}$, has been shown in both natural and synthetic assemblages to be large and strongly temperature dependent. Two general experimental calibrations of the exchange thermometer have been carried out in mafic systems (Raheim and Green, 1974; Ellis and Green, 1979). In addition, several semi-empirical and theoretical studies by Mysen and Heier (1972), Ganguly (1979), Wells (1979), Dahl (1980), Ganguly and Saxena (1987) and Yang (1994) have been based on a selective input of experimental data and attempted reproduction of expected temperatures of natural parageneses.

Raheim and Green (1974) presented a geothermometer, on the basis of experimental studies and natural observations. Their formulation is:

$$
\mathrm{T}(\mathrm{K})=\frac{\left(3686+28.35^{*} \mathrm{P}\right)}{\left(\ln \mathrm{K}_{\mathrm{D}}+2.33\right)}
$$

Mysen and Heier (1972) proposed an empirical calibration for the garnet-clinopyroxene thermometer:

$$
T(K)=\frac{2475}{\left(\ln K_{D}+0.781\right)}
$$

where $K_{D}$ is same as defined by Raheim and Green (1974) for this as well as the subsequently discussed thermometer.

Ellis and Green (1979) presented a geothermometer on the basis of experimental studies. They considered the effect of $\mathrm{Ca}$ upon garnet-clinopyroxene. Their formulation is as follows:

$$
\mathrm{T}(\mathrm{K})=\frac{\left(3104 * \mathrm{X}_{\mathrm{Ca}} \mathrm{gt}^{\mathrm{t}}+3030+0.01086 *(\mathrm{P}-1)\right)}{\left(\ln \mathrm{K}_{\mathrm{D}}+1.9034\right)}
$$

Ganguly (1979) has examined the effects of Mn, $\mathrm{Ca}$ and $\mathrm{P}$ and gave the following formulation, based on integrated thermochemical and experimental data:

$$
\mathrm{T}(\mathrm{K})=\frac{\left(4801+11.07 * \mathrm{P}(\mathrm{kb})+1586 * \mathrm{X}_{\mathrm{Ca}^{\mathrm{gt}}}+1308 * \mathrm{X}_{\mathrm{Mn}}{ }^{\mathrm{gt}}\right)}{\left(\ln \mathrm{K}_{\mathrm{D}}+2.93\right)}
$$

Wells (1979) has also presented a geothermometer for calculation of equilibrium temperature of the granulite facies assemblages from the composition of coexisting garnet and clinopyroxene. Assuming that the departures from ideal mixing in the pyroxene and garnet phases are mutually cancelled out, Wells gave the following equation:

$$
\mathrm{T}(\mathrm{K})=\frac{(24440+0.06524 *(\mathrm{P}-1))}{\left(13.41-3 * \mathrm{R} \ln \mathrm{K}_{\mathrm{D}}\right)}
$$

Dahl (1980) presented a geothermometer on the basis of empirical studies and his formulation is as follows:

$$
\frac{759.44 \times\left(\mathrm{X}_{\mathrm{Fe}}-\mathrm{X}_{\mathrm{Mg}}{ }^{2}+1414 \times \mathrm{X}_{\mathrm{Ca}}{ }^{\mathrm{gt}}+1437 \times \mathrm{X}_{\mathrm{Mn}}{ }^{\mathrm{gt}}\right)}{\ln \mathrm{K}_{\mathrm{D}}}
$$

Ganguly and Saxena (1987) modified the equation given by Ganguly, 1979 on the basis of empirical studies and the modified equation is given below:

$\mathrm{T}(\mathrm{K})=\frac{\left(4100+0.01107 *(\mathrm{P}-1)+1510 *\left(\mathrm{X}_{\mathrm{Ca}}+\mathrm{X}_{\mathrm{Mn}}\right)^{\mathrm{gt}}\right)}{\left(\ln _{\mathrm{D}}+2.40\right)}$

Yang (1994) presented a geothermometer on the basis of empirical studies and his formulation is as follows:

$$
\mathrm{T}(\mathrm{K})=\frac{\begin{array}{r}
{\left[1987.98+(0.01766 * \mathrm{P})-\left(1629 * \mathrm{X}_{\mathrm{Ca}}{ }^{*} \mathrm{X}_{\mathrm{Ca}}\right)+\right.} \\
\left.\left(3648.55 * \mathrm{X}_{\mathrm{Ca}}\right)-(6.59 * \mathrm{MgNo})\right]
\end{array}}{\left(\ln \mathrm{K}_{\mathrm{D}}+1.076\right)}
$$

where, $\mathrm{MgNo}=(100 \times \mathrm{MGGT}) /(\mathrm{MGGT}+\mathrm{FEGT})$

\section{BACKGROUND OF GARNET- CLINOPYROXENE-PLAGIOCLASE- QUARTZ GEOBAROMETERS}

The assemblage garnet-clinopyroxeneplagioclase-quartz in basic granulites represent a potential geobarometer. The four-phase assemblage is represented by the reactions:

$$
\begin{aligned}
& \mathrm{CaAl}_{2} \mathrm{Si}_{2} \mathrm{O}_{8}+\mathrm{CaMgSi}_{2} \mathrm{O}_{6}=2 / 3 \mathrm{Ca}_{3} \mathrm{AlSi}_{3} \mathrm{O}_{12}+1 / 3 \mathrm{Mg}_{3} \mathrm{Al}_{2} \mathrm{Si}_{3} \mathrm{O}_{12}+\mathrm{SiO}_{2} \\
& \text { Anorthite + Diopside }=2 / 3 \text { Grossularite }+1 / 3 \text { Pyrope +Quartz } \\
& \mathrm{K} 1=\frac{\left(\mathrm{a}_{\mathrm{Ca}}{ }^{\mathrm{gt}}\right)^{2} * \mathrm{a}_{\mathrm{Mg}}{ }^{\mathrm{gt}}}{\left(\mathrm{a}_{\mathrm{An}}{ }^{\mathrm{Plag}} * \mathrm{a}_{\mathrm{Diop}}{ }^{\mathrm{Cpx}}\right)}
\end{aligned}
$$


MPET4: a computer program for garnet-clinopyroxene-plagioclase-quartz geothermobarometry

$$
\mathrm{K} 1=\frac{\left(\mathrm{a}_{\mathrm{Ca}}{ }^{\mathrm{gt}}\right)^{2} * \mathrm{a}_{\mathrm{Fe}} \mathrm{gt}^{\mathrm{gt}}}{\left(\mathrm{a}_{\mathrm{An}}{ }^{\mathrm{Plag}} * \mathrm{a}_{\mathrm{Hed}}{ }^{\mathrm{Cpx}}\right)}
$$

These reactions have large volume changes and hence are highly suitable for geobarometry. Newton and perkins (1982) have also calibrated reaction as:

$$
\mathrm{P}_{\mathrm{Mg}}=1+\frac{\left(\mathrm{T}^{*}(9.493+\mathrm{R} \ln \mathrm{K} 1)+373\right)}{0.55258}
$$

According to Newton and Perkins (1982), the combined uncertainties in the thermochemically measured standard Gibbs energies lead to uncertainty of 1700 bars for this barometer at a given temperature.

Moecher et al. (1988) presented a geobarometer on the basis of thermodynamic studies and their formulation are as follows:

$$
\begin{gathered}
\mathrm{P}_{\mathrm{Mg}}=1+\frac{\left[\mathrm{T}^{*}(* 11.314+\mathrm{R} \ln \mathrm{K} 1)-1103\right]}{0.5411} \text { and } \\
\mathrm{P}_{\mathrm{Fe}}=1+\frac{\left[\mathrm{T}^{*}(12.773+\mathrm{R} \ln \mathrm{K} 2)-4924\right]}{0.5588}
\end{gathered}
$$

Eckert et al. (1991) gave the $\mathrm{pH}$ of reaction and recalibrated the garnet-pyroxene-plagioclase-quartz geobarometers in the CMAS systems by solution calorimetry.

$$
\mathrm{P}_{\mathrm{Mg}}=1+\frac{\left[\mathrm{T}^{*}(9.4885+\mathrm{R} \ln \mathrm{K} 1)+1491\right]}{0.53200}
$$

Holland and Powell (1985) gave the geobarometer based on an internally consistent themodynamic dataset, which Eckert et al. (1993) calibrated thermochemically.

$$
\mathrm{P}_{\mathrm{Mg}}=1+\frac{\left[\mathrm{T}^{*}(8.891+\mathrm{R} \ln \mathrm{K} 1)+1224\right]}{0.53203}
$$

Holland and Powell (1990) gave the geobarometer based on an internally consistent the thermodynamic dataset with uncertainties and correlations: In $\mathrm{K}_{2} \mathrm{O}-\mathrm{NaO}-\mathrm{CaO}-\mathrm{MgO}-\mathrm{MnO}-\mathrm{FeO}-$ $\mathrm{Fe}_{2} \mathrm{O}_{3}-\mathrm{Al}_{2} \mathrm{O}_{3}-\mathrm{TiO}_{2}-\mathrm{SiO}_{2}-\mathrm{C}-\mathrm{H}_{2}-\mathrm{O}_{2}$ system, which Eckert et al., 1993, recalibrated thermochemically and gave the equation given below:

$$
\mathrm{P}_{\mathrm{Mg}}=1+\frac{[\mathrm{T} *(10.2055+\mathrm{R} \operatorname{lnK} 1)+733]}{054254}
$$

Berman (1988) presented the internallyconsistent thermodynamic data for stoichiometric minerals in the system $\mathrm{Na}_{2} \mathrm{O}-\mathrm{K}_{2} \mathrm{O}-\mathrm{CaO}-\mathrm{MgO}-\mathrm{FeO}-$ $\mathrm{Fe}_{2} \mathrm{O}_{3}-\mathrm{SiO}_{2}-\mathrm{TiO}_{2}-\mathrm{H}_{2} \mathrm{O}-\mathrm{CO}_{2}$, which Eckert et al. (1993) recalculated thermochemically and gave the equation:

$$
\begin{aligned}
& \mathrm{P}_{\mathrm{Mg}}=1+\frac{\left[\mathrm{T}^{*}(10.1577+\mathrm{R} \operatorname{lnK} 1)+315\right]}{0.54135} \\
& \text { PROGRAM DESCRIPTION }
\end{aligned}
$$

The software consists of three programs as it is clear from the program flowchart (Fig. 1). Being an interactive package, it prompts the user for a choice of:

(1) Gt-Cpx exchange reaction (GCtherm)

(2) Gt-Cpx-Plag-Qz equilibria (GCPQ)

(3) Exit.

If the temperature calculation is intended through garnet-clinopyroxene exchange reaction, enter the Option No. 1. It automatically proceeds into the subprogram $<<$ GCtherm $>>$ for calculation.

Beside this, GCtherm also consists of three subprograms as shown on the flowchart (Fig. 1). On running, it prompts the user three choices, viz., "ENTER DATA", "CALCULATE AND DISPLAY RESULTS" and "EXIT" from GCtherm. The first choice is "ENTER DATA", when opted asks for a file name. The selected file is opened and displayed on the screen. If the file asked for does not exist, then a file by the asked name is automatically created. The program then asks for data. The data requirement is in the form of structural formula units or atomic formula units (a.f.u.) of $\mathrm{Fe}, \mathrm{Mg}, \mathrm{Ca}, \mathrm{Mn}$ for garnet and $\mathrm{Fe}$ and $\mathrm{Mg}$, for clinopyroxene. Pressure (in bars) at which the temperature is to be calculated is also required. The data entry operation can be terminated by entering 0 (zero) at the S.No. prompt.

The second choice (CALCULATE AND DISPLAY RESULTS), however requires the data file name. The program first displays the data file contents then proceeds for calculation of temperature through different models. This program may be looked upon as an operational block, which performs the specific operations on the data to provide the output in a fixed format. 


\section{H. Thomas}
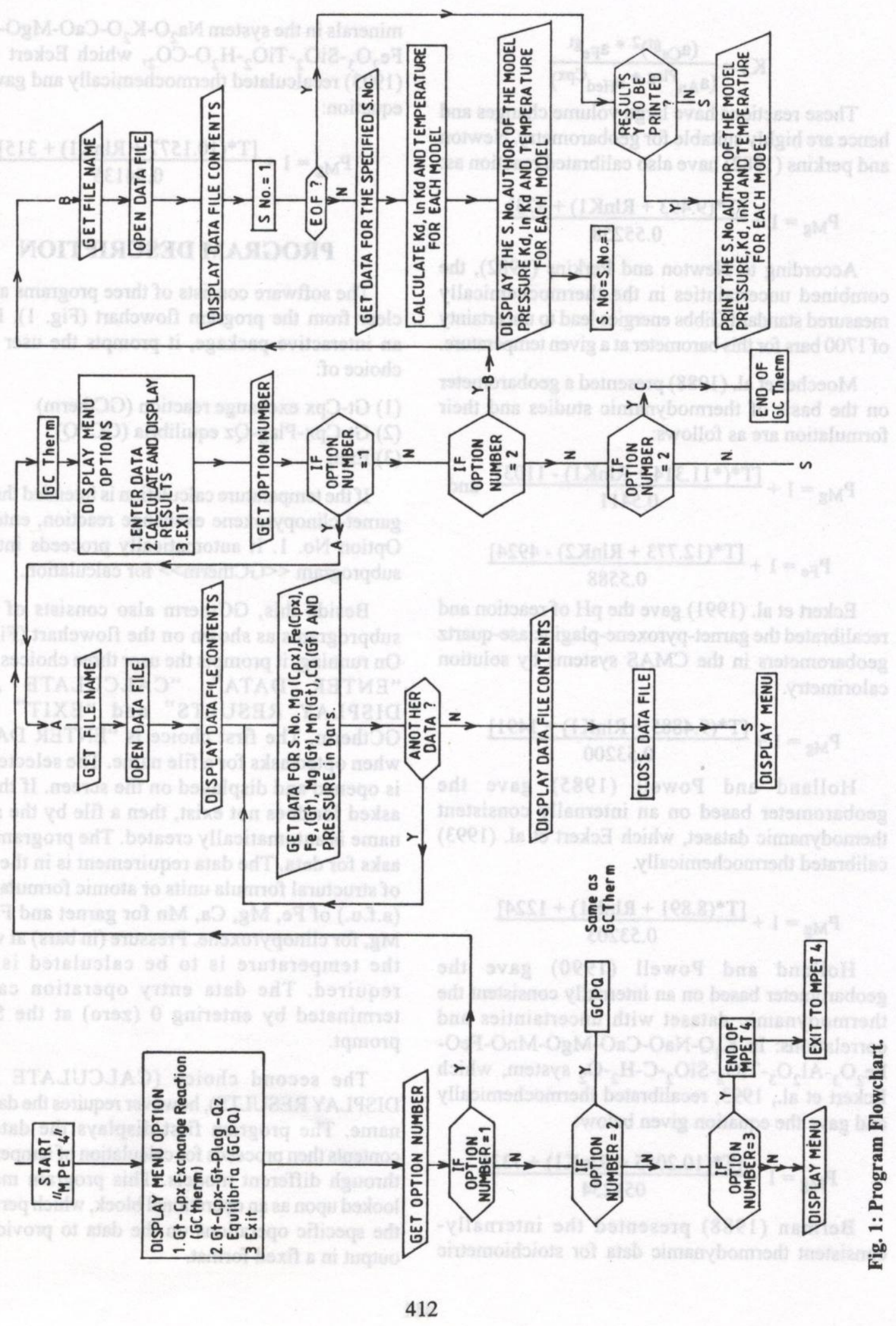
The third option terminates the program and return to the main menu.

In a similar way, if the user wishes to calculate pressure through garnet-clinopyroxeneplagioclase-quartz equilibria (GCPQ), option No. 2 is to be entered. The program automatically enters into the subprogram (GCPQ) for pressure calculation. It also works like GCtherm subprogram. The data requirement in this program is also in the form of structural formula units or atomic formula units (a.f.u.) of $\mathrm{Fe}, \mathrm{Mg}, \mathrm{Ca}, \mathrm{Mn}$ for garnet, $\mathrm{Ca}, \mathrm{Na}, \mathrm{K}$ for plagioclase and $\mathrm{Fe}, \mathrm{Mg}$, $\mathrm{Ca}, \mathrm{Al}^{6}, \mathrm{Fe}^{3}, \mathrm{Cr}$ and $\mathrm{Ti}$ for clinopyroxene. Temperature (in $\mathrm{K}$ ) at which the pressure is to be calculated is also required. The data entry operation can be terminated by entering 0 (zero) at the S.No. prompt. Rest of the options are also work like Gotherm subprogram. Copy of the computer program "MPET4" (Executable code; MPET4.EXE) can be acquired from the author by sending a unformatted $3.5 " / 5.25$ " disk.

\section{PROGRAM VALIDATION}

Validation of the computer program (MPET4), several data had been manually calculated (Thomas, 1991) and reprocessed through this computer program. It was observed that all the results are same as manually calculated. For example, one set of data is given in Table 1 and the results obtained are shown in Table 2 and 3. Although there is some variation among the results obtained from individual formulation. This discrepancy might be due to the fact that some of the formulations are based on the empirical studies, some on experimental works. Comparison of different calibrations require more enhaustive discussion, therefore, the author feels that experimentally calibrated formulations should be the preferred geothermobarometer.

\section{ACKNOWLEDGEMENT}

The author is thankful to Prof. R.S. Sharma, for his consistent encouragement and valuable

Table 1: Electron micro-probe analyses (Wt\%) and structural formulae (24 Oxygen basis) of garnet, (6 Oxygen basis) of clinopyroxene and (8 Oxygen basis) of plagioclase in basic granulite from Thana, District Bhilwara, Rajasthan.

\begin{tabular}{|l|r|r|r|}
\hline Oxides & $\begin{array}{r}\mathrm{H} 90 / 9 \\
\text { Clinopyroxene } \\
\text { point } 44\end{array}$ & $\begin{array}{r}\mathrm{H} 90 / 9 \\
\text { Garnet } \\
\text { point } 46\end{array}$ & $\begin{array}{r}\mathrm{H} 90 / 9 \\
\text { Plagioclase } \\
\text { point } 47\end{array}$ \\
\hline $\mathrm{SiO}_{2}$ & 50.707 & 37.536 & 56.334 \\
$\mathrm{TiO}_{2}$ & 0.801 & 0.000 & 0.000 \\
$\mathrm{Al}_{2} \mathrm{O}_{3}$ & 1.977 & 21.483 & 27.280 \\
$\mathrm{FeO}$ & 11.355 & 28.001 & 0.151 \\
$\mathrm{MnO}$ & 0.136 & 0.908 & 0.000 \\
$\mathrm{MgO}$ & 12.559 & 6.037 & 0.000 \\
$\mathrm{CaO}$ & 20.526 & 6.898 & 9.979 \\
$\mathrm{~K}_{2} \mathrm{O}$ & 0.008 & 0.000 & 0.092 \\
$\mathrm{Na} 2 \mathrm{O}$ & 0.916 & 0.000 & 5.995 \\
\hline $\mathrm{Total}$ & & & 99.649 \\
\hline $\mathrm{Si}$ & 98.986 & 100.863 & 2.5404 \\
$\mathrm{Ti}$ & 1.9227 & 5.8563 & 0.0000 \\
$\mathrm{Al}$ & 0.0228 & 0.0000 & 1.4499 \\
$\mathrm{Fe}$ & 0.0884 & 3.9501 & 0.0000 \\
$\mathrm{Mg}$ & 0.0882 & 0.0818 & 0.0000 \\
$\mathrm{Ca}$ & 0.7098 & 1.4038 & 0.4734 \\
$\mathrm{Mn}$ & 0.8339 & 1.1531 & 0.0000 \\
$\mathrm{Fe}$ & 0.0044 & 0.1200 & 0.0057 \\
$\mathrm{Na}$ & 0.2620 & 3.5626 & 0.5242 \\
$\mathrm{~K}$ & 0.0674 & 0.0000 & 0.0053 \\
\hline
\end{tabular}




\section{H. Thomas}

Table 2: Temperature (in ${ }^{\circ} \mathrm{C}$ ) calculated by GCtherm subprogram.

\begin{tabular}{|c|c|c|c|}
\hline Pressure (bars) 7000 & $\mathbf{K}_{\mathbf{p}}$ & $\ln K_{\mathrm{D}}$ & Temper \\
\hline \multicolumn{4}{|c|}{$1 / 3$ Pyrope + Hedenbergite $=1 / 3$ Almandine + Diopside } \\
\hline 72) & 6.8754 & 1.9279 & 640 \\
\hline & 4 & & 39 \\
\hline Ell & 6.8754 & 79 & 687 \\
\hline 79 & 6.8754 & 1.9279 & 797 \\
\hline & 6.8754 & 1.9279 & 727 \\
\hline & 6.8754 & 1.9 & 660 \\
\hline Saxena (1987) & $\begin{array}{l}6.8754 \\
6.8754\end{array}$ & & 763 \\
\hline Yang & $0.8 / 34$ & 1.5 & \\
\hline
\end{tabular}

\begin{tabular}{|c|c|c|c|c|c|}
\hline $\mathrm{X}_{\mathrm{Fe}(\mathrm{G} t)}$ & $\mathrm{X}_{\mathrm{Mg}(\mathrm{Gt})}$ & $\mathrm{X}_{\mathrm{Ca}(\mathrm{Gt})}$ & $\mathrm{X}_{\mathrm{Mg}(\mathrm{Gt})}$ & $\mathrm{X}_{\mathrm{Fe}(\mathrm{Cpx})}$ & $\mathrm{X}_{\mathrm{Mg}(\mathrm{Cps})}$ \\
\hline 0.570975 & 0.224986 & 0.184806 & 0.019232 & 0.269703 & 0.730397 \\
\hline
\end{tabular}

Table 3: Pressure (in kbar) calculated by GCPQ subprogram.

\begin{tabular}{|l|c|c|}
\hline \multicolumn{1}{|c|}{ Temperature (K) 923 } & 1nK $_{\mathbf{D}}$ & Pressure (Kbar) \\
\hline \multicolumn{2}{|c|}{ Anorthite+Diopside =2/3 Grossularite + 1/3 Pyrope + Quartz } \\
\hline Newton and Perkins (1982) & -3.3443 & 5.43 \\
Moecher et al. (1988) & -2.6835 & 8.17 \\
Eckert et al. (1991) & -3.3443 & 7.74 \\
Holland and Powell (1985) calculated by Eckert et al. (1993) & -3.3443 & 6.20 \\
Holland and Powell (1990) calculated by Eckert et al. (1993) & -3.3443 & 7.41 \\
Berman (1988) calculated by Eckert et al. (1993) & -3.3443 & 6.57 \\
Berman (1988) calculated by Eckert et al. (1993) using Ca-Fe-Mg & -2.9841 & 7.79 \\
subregular solution of mixing in garnet. Berman (1990) & \multicolumn{2}{|c|}{ Anorthite + Hedenbergite = 2/3 Grossularite + 1/3 Almandine+Quartz } \\
\hline \multicolumn{2}{|c|}{ Anorther } \\
\hline Moecher et al. (1988) & -1.4480 & 7.53 \\
\hline
\end{tabular}

suggestions throughout this work. He is grateful to Prof. R.K. Lal, for his guidance and fruitful discussions. The author acknowledges the financial assistance received from the DST, New Delhi for his Young Scientist Project (SR/0Y/A-01/94).

\section{REFERENCES}

Berman, R.G., 1988, Internally-consistent thermodynamic data for stoichiometric minerals in the system $\mathrm{Na} 2 \mathrm{O}-$ $\mathrm{K}_{2} \mathrm{O}-\mathrm{CaO}-\mathrm{MgO}-\mathrm{FeO}-\mathrm{Fe}_{2} \mathrm{O}_{3}-\mathrm{SiO}_{2}-\mathrm{TiO}_{2}-\mathrm{H}_{2} \mathrm{O}-\mathrm{CO}_{2}$. Jour. Petrol., v. 29, pp. 445-522.

Berman, R.G., 1990, Mixing properties of Ca-Mg-Fe-Mn garnet. Am. Mineralogist, v. 75, pp. 328-344.

Dahl, P.S., 1980, The thermal comositional dependence of $\mathrm{Fe}^{+2}-\mathrm{Mg}^{+2}$ distributions between coexisting garnet and pyroxene: application to geothermometry. Am. Mineralogist, v. 65, pp. 852-866.
Eckert, J.O. Jr., Newton, R.C. and Kleppa, O.J., 1991, The $\mathrm{pH}$ of reaction and recalibration of garnet-pyroxene-plagioclase-quartz geobarometers in the CMAS systems by solution calorimetry, Am. Mineral., v. 76, pp. 148-160.

Eckert, J.O. Jr., and Newton, R.C., 1993, Palaeopressure of South India two pyroxene garnet granulites from thermochemically calibrated barometers., Jour. Meta. Geol., V.11, p.845-854.

Ellis, D.J. and Green, H.D., 1979, An experimental study of the effect of $\mathrm{Ca}$ upon garnetclinopyroxene $\mathrm{Fe}-\mathrm{Mg}$ exchange equilibria., Contrib. Mineral and Petrol., v. 71, pp. 13-22.

Ganguly, J., 1979, Garnet and clinopyroxene solid solutions and geothermometry based on Fe$\mathrm{Mg}$ distribution coefficient, Geochim. Cosmochim. Acta., v. 43, pp. 1021-1029. 
MPET4: a computer program for garnet-clinopyroxene-plagioclase-quartz geothermobarometry

Ganguly, J., and Saxena, S.K., 1987, Mixtures and mineral reactions. In: A. EL. Goresy and Von Engelhardt, W. (eds.), Mineral and Rocks, v. 19, Springer-Verlag, Berlin.

Holland, T.J.B., and Powell, R., 1985, An internally consistent thermodynamic dataset with uncertainties and correlations: 2. Data and results, Jour. Meta. Geol., v. 3 , pp. $343-370$.

Holland, T.J.B. and Powell, R., 1990, An enlarged and updated internally consistent thermodynamic data set with uncertainties and correlations: the system $\mathrm{K}_{2} \mathrm{O}$ $\mathrm{Na}_{2} \mathrm{O}-\mathrm{CaO}-\mathrm{MgO}-\mathrm{MnO}-\mathrm{FeO}-\mathrm{Fe}_{2} \mathrm{O}_{3}-\mathrm{Al}_{2} \mathrm{O}_{3}-\mathrm{TiO}_{2}-$ $\mathrm{SiO}_{2}-\mathrm{C}-\mathrm{H}_{2}-\mathrm{O}_{2}$. Jour. Meta. Geol., v. 8, pp. 89-12.

Moecher, D.P., Essene, E.J., and Anovitz, L.M., 1988, Calculation and application of clinopyroxene-garnetplagioclase-quartz geobarometers, Contrib. Mineral. and Petrol., v. 100, pp. 92-106.

Mysen, B.O., and Heier, K.S., 1972, Petrogenesis of ecologites in high grade metamorphic gneisses, exemplified by the Hareidland Ecologites, western Norway. Contrib. Mineral. and Petrol, v. 36, pp. 73-94.
Newton, R.C. and Perkins, D., 1982, Thermodynamic calibration of geobarometers based on the assemblages garnet-plagioclase-orthopyroxene(clinopyroxene)-quartz. Am. Mineral., v. 67, pp. 203-222.

Raheim, A. and Green, D.H., 1974, Experimental determination of the temperature and pressure dependence of the Fe-Mg partition coefficient for coexisting garnet and clinopyroxene, Contrib. Mineral. and Petrol., v. 48, pp. 179-203.

Thomas, H., 1991, Petrographic study and petrogenesis of the Precambrian rocks around Thana districtBhilwara, Rajasthan. Unpubl. Ph.D. thesis, Banaras Hindu University, Banaras, India.

Wells, P.R.A., 1979, Chemical and thermal evolution of Archacan sialic crust, southern West Greenland. Jour. Petrol., v. 46, pp. 1-15.

Yang, A.I., 1994, A revision of garnet-clinopyroxene $\mathrm{Fe}^{+2}$ - Mg exchange geothermometer., Contrib. Mineral. and Petrol., v. 115(9), pp. 467-473. 